\title{
Influence of the Investigation Process on the Political, Economic and Social Status of the Accused in Criminal Cases in Vietnam
}

\author{
Bui Cong Phu ${ }^{1,2, *}$, Bui Doan Hien ${ }^{3}$, Vu Trinh Hai Viet ${ }^{3}$
}

\author{
${ }^{1}$ People's Friendship University of Russia, Moscow, Russia \\ ${ }^{2}$ T08 - Ministry of Public Security of Socialist Republic of Vietnam, Vietnam \\ ${ }^{3}$ T05 - Ministry of Public Security of Socialist Republic of Vietnam, Vietnam \\ *Corresponding author. Email: Buicongphut37@gmail.com
}

\begin{abstract}
According to the regulations of Vietnamese law, the accused is the person prosecuted with a criminal charges. Currently, Vietnam has made many judicial reforms to improve human rights, including reforms in criminal proceedings to protect the human rights of accuseds. However, in reality, due to many objective and subjective reasons, the accused's rights are not guaranteed. Especially in the process of investigation, creating adverse effects on the political, economic and social rights of the accuseds. During special investigation and proceedings, the accused's rights are the most seriously affected. In the framework of the article, the author assesses the impact of these activities in the investigation on the accused. Beside, proposing solutions to protect accuseds, including the need for authorities to compensate for political, economic and social damage caused by the violation of law provisions during the investigation in Vietnam.
\end{abstract}

Keywords: investigation process, political, economic, social status, Vietnam's economy

\section{INTRODUCTION}

International human rights law has minimum standards to ensure the legitimate rights and interests of in criminal proceedings, that are applied in a global scale, regardless of the political system or economic and social development. The system of minimum standards of human rights in criminal proceedings is prescribes in many documents, which can be found in international human rights documents in criminal proceedings such as: Universal Declaration of Human Rights 1948 (UHDR); International Covenant on Civil and Political Rights 1966 (ICCPR); Basic Principles for the Treatment of Prisoners 1990; United Nations Convention against Torture and Other Cruel, Inhuman or Degrading Treatment or Punishment... The provisions in the above documents constitute a system of minimum standards of conduct of authorities and law enforcement staff as well as ensure that the accusers and accuseds have certain legal rights to protect their legitimate rights and interests, and minimize the risks of illegal abuse [1].

Currently, Vietnam is a member of international conventions such as: ICCPR (joined in 1982); Convention on the Rights of the Child (joined 1990); Convention on the Non-Applicability of Statutory Limitations to War Crimes and Crimes Against Humanity 1968 (joined 1983). Vietnam always strive to fulfil its commitments while actively cooperating with countries and national organizations, upholding individuals 'human rights and the responsibility of law enforcement authorities, respecting and ensuring performance in order to minimize the risk that may infringe the rights and legitimate interests of individuals in public service. The influence of the criminal proceedings on the accused's political, economic and social status is enormous [2-5]. However, in this article, the author focuses on assessing the impact of the investigation process in criminal cases.

\section{THE INVESTIGATION PROCESS AND THE ACCUSEDS' RIGHTS IN VIETNAMESE LAW}

In the process of investigating a criminal case, the authorities shall base on the provisions of the criminal procedure code and, under the supervision of the Procuracy take necessary measures to collect and consolidate criminal evidence, studying the facts of criminal cases, quickly and fully detecting criminals, as well as those at fault in the perpetrator of the crime to face criminal charges, while ensuring that compensation for damage caused by the crime and based on it to decide: to suspend the investigation of the criminal case or; Transfer all documents of the case to the Procuracy with the conclusion of the investigation and request to prosecute the accuseds [6].

The criminal investigation process has the main roles and meanings:

Firstly, criminal investigation is an important function of the criminal justice agency of the authorities (people) carries out authority for each criminal offense to directly prove the criminal actions and the perpetrator of the crime 
through the evidence gathered, and it is also one of the basic means to well implement the principle of unavoidability of liability to apply in the practice of criminal procedure law to avoid missing criminals.

Secondly, investigation also contributes to eliminating another extreme in criminal justice activities, preventing in a timely manner the carefulness and inaccurate passing of decisions on pressing charges. Therefore, there may lead series of negative consequences in sentencing with criminal records sustained at various stages of criminal proceedings (such as: Prosecuting by the Procuracy or judging by the Court in bias and illegal way, that slanders innocent people);

Thirdly, investigation of criminal cases is a basic and important criminal procedure stage to strengthen the law, protect the rights and freedoms of citizens in the preprosecution stages of the Procuracy and the Court's adjudication, along with other stages of criminal proceedings, effectively contribute to the fight against crime in society.

Rights and obligations of accuseds and accusers in criminal proceedings are a very important issue that directly affects the proceedings. In the past, the accuseds were automatically considered guilty, so their rights are greatly reduced. But with the new Criminal Procedure Code 2015, there have been amendments compared with the 2003 Criminal Procedure Code, which not only provide more specific and clearer provisions, but also expand the rights of accuseds to ensure merit in criminal law enforcement.

Firstly, the right to "know the reasons for being prosecuted". Accuseds need to know what crime they are being charged with, and why they are being prosecuted. Without that right, they cannot realize their right to defend. The reason for the accused's explanation is also for the accused to grasp information and to take the initiative in perform his right to defend. The responsibility to explain to the accuseds in this case belongs to the investigation authorities and procuracies.

Secondly, the right to "present opinions on evidences, documents and related objects and request authorities to examine and evaluate". After presenting evidences, documents, objects or requests, in order to incriminate themselves or use them as extenuating circumstances, the accused has the right to express his or her opinion on those objects, and if it was necessary, they could to ask individuals given authority to inspect and evaluate the authenticity and correctness of these objects. It helps the accused to prove themselves innocent and helps the investigation process quickly as well as the truth of the case.

Thirdly, the right to "read, write down copies of documents or digitized documents relating to the charges, indictment or other copies of documents related to the defence from the end of the investigation;" - This is one of the most important rights of the accused, and is considered the most practical. Some opinions think that in the current situation, with the level of the investigation organizations and staffs, investigation activities do not fully, comprehensively and objectively guarantee, so if the accused check documents related to an accusation or detainment, they would find to deny or obstruct the investigation. Therefore, they assumed that the accused should only know the conclusion of the investigation after the investigation is completed.

However, it is important to ensure that the accused review all documents related to the incrimination, detention, as well as the defence after the investigation has ended so that the accused know that he has been charged by what evidence. From there, the accused can perform his right to defend well. The accused who can review of the document will help to overcome the shortcomings and inadequacies in the investigation process as well as the conduct of an objective and comprehensive investigation. If the investigative agency has gathered enough evidence to charge, there is no reason they should be afraid of the accused looking at those documents. This makes the investigator have more responsibilities in the process of investigating the case.

\section{INTERROGATION AND SPECIAL METHODS OF INVESTIGATION}

During the first interrogation, the Procurator is required to participate in supervising the Interrogation of Investigators, unless objectively they unable to participate, they must immediately participate in the next time. When interrogating a suspect at a detention facility or at the office, of an investigating authorities have to audio or video recordings, procurators must request investigators to fully explain their rights and obligations in accordance with Article 60 Criminal procedure code and such explanations must be recorded with sound. There are some opinions that the explanation is provided for before interrogation and does not need to include audio or video recording content. Such interpretation is not accurate, because the explanation of rights and obligations must determine that the content is important and must be included in the audio or video recording content, because this is a mandatory provision of procedural. Procurators must firmly request for the time that is record soon as possible, and at the same time, right after completely explaining of rights and obligations. After that, they must be confirm that the accused is explained clearly full rights and obligations [7, 8]].

During the next interrogation, investigator can continue to ask the accused that he fully understands his rights and obligations, if he did not remember, it was necessary to explain again. In case the accused has an opinion on the perform of one of the rights provided for in Article 60 of the Criminal procedure code, investigators must take measures to ensure that they comply with law. In this way, the explanation of the accused's rights and obligations is done in the most complete and effective way.

Measures to secure the accused's right to request when interrogating. Before interrogating the accused, procurators must request investigators to clearly inform them that the interrogation is recorded with audio in 
accordance with the law so that they are mentally prepared as well as take the initiative in your testimony and know that this recording or recording will be public evidence at the hearing. Investigators are not allowed to record or video in illegal cases such as recording or video recording in the form of non-public, secretly filmed, mutilated testimony ... and this notice must be recorded. In the minutes of interrogation of the accused, the provisions of the law are ensured.

In case of interrogation of the accused at another place, where is recording with audio or video shall requested by the accused. To ensure this right, if interrogation is required at another location, it is imperative that the Investigator be required to explain and ask whether the accused has requested audio or video recording or not. Without explaining, it is natural that the cannot know this provision, because Article 60 of the Criminal procedure code only provides general provisions on the right to request. Be aware that, in a particular case when the accused requires a sound recording or video recording, it is imperative that it be made; if no sound recording or video recording is made, the interrogation must stop. If the accused agrees to continue the interrogation without sound recording or video recording, the interrogation will be conducted normally and this questioning must be recorded in the interrogation minutes of the accused.

According to Article 223 of the 2015 Law on Criminal Procedure [9], special measures for investigation and proceedings include secretly recording; taking the phone secretly; confidential collection of electronic data. In which, secret recording is a measure of recording the content of the conversation and exchange of the suspect objects in the case with each other; recording the conversation between the suspect and the criminal whistleblower... Secret video recording is a measure of recording images of the suspect committing criminal acts to prove, clarify the developments and calculations nature of the offense. Secret phone listening is a means of listening and can record the words of the suspect to supplement evidence proving the suspect's criminal behaviour. The secret method of listening to the phone can record the subject's discussion and discussion when preparing to commit the crime, the manifestations in the process as well as when the offense has been committed $[10,11]$. Secret collection of electronic data is the secret collection of information in electronic form such as symbols, letters, numbers, images, sounds created, stored, transmitted by means electronic. Electronic data can be encrypted, hidden by the intent of the user, especially for high-tech criminals when criminals often find ways to hide information and documents related to his crime.

With the characters of new regulations, first being stipulated in Vietnam in a legal document, in addition, these are sensitive investigative measures, when implemented, there may be having a great impact on the fundamental rights of people and citizens, the strict supervision in the application of investigation measures is especially important to ensure human rights and public rights people are not violated in criminal proceedings. Therefore, the Procuracy's supervisory activities during the proceedings play a particularly important role. On the other hand, due to that "special" character, these investigative measures are only deployed in a number of special crimes with relatively limited scope of application such as: Crime of violating national security; drug-related crimes; crime of corruption; crime of terrorism; money laundering; other organized crimes are of particularly serious crimes.

The application of special methods of investigation and proceedings must always ensure a balance between the interests of the state, the requirement to fight crime prevention and fight and the request to protect human rights in criminal proceedings. . Although the 2015 Criminal Procedure Code has strictly defined the order, procedures, competence and time limit for application of these measures. However, in reality, it is quite reasonable to wonder if there are any violations when applying this measure. The subject of supervising this activity The Procuracy and directly the procurators also need to make great efforts in improving their qualifications, updating new knowledge, summarizing and drawing experience to be able to perform well functions in this particular field. Therefore, this is really a big challenge in the process of implementing inspection activities.

\section{CUSTODY AND TEMPORARY DETENTION IN THE COURSE OF INVESTIGATION}

Custody and temporary detention are measures to prevent some of the human rights and civil rights of persons held in custody or temporary detention. The purpose of these measures is to ensure procedural agencies to properly perform their functions and duties in the fight against and prevent crime, and to ensure legal order. When applying preventive measures, it is imperative to have a firm grasp of the contents, competence and procedures for arrest, custody and temporary detention, ensuring legal procedure-conducting agencies and procedure-conducting people properly apply rightly the law, avoid violating the laws on ensuring human rights and citizen's rights when performing official duties.

Inheriting the provisions of the 1992 Constitution; The 2013 Constitution states: "Everyone has the right to body inviolability, to be protected by the law in terms of health, honor and dignity, ..."; "No one will be arrested without a decision of the People's Court, a decision or approval of the People's Procuracy, except in the case of a crime in the act of ..."

Clause 5 Article 31 of the 2013 Constitution emphasizes "Persons who are arrested, detained, prosecuted, investigated, tried and executed against the law have the right to be compensated for object and spirit damage and honor recovery...".

Detention is a deterrent measure in criminal proceedings applied by authorities and people given authority to people arrested in an emergency or committing crime, confessing or surrendering to a criminal people arrested 
under a warrant to prevent acts that are dangerous to their society, prevent them from continuing to commit crimes, evade the law or act to obstruct the investigation, prosecution or adjudication, judgment execution.

In recent years, the custody and detention of people have attracted the attention of many state agencies, social organizations, and the masses of people. Arbitrary arrest, unjust arrest of innocent persons, and custody of persons without orders have seriously affected human rights, legal rights and interests of citizens. There are cases where the inferior agencies keep the person but fail to report to the competent agency, handle the case arbitrarily, seriously harm the right to freedom, the right to be protected with respect to human honor and dignity, affects the reputation of our State and the proceeding agencies.

Arbitrary application of preventive measures such as custody or detention in contravention of procedures, authority, overdue, all seriously affect human rights, legal rights and interests of citizens. infringes upon the inviolable right to the body and political life of people and citizens, reduces the prestige of our Party and State, reduces the people's confidence in progressive agencies. practice. Therefore, the correct and full understanding and strict implementation of the provisions of the law on preventive measures will improve the effectiveness of the fight against and prevent crime; thereby making an important and necessary contribution to ensuring human rights.

Detention of accused means detention of a person who has been criminally prosecuted or a person who has been brought to trial by a court in order to serve the investigation, prosecution, adjudication and enforcement of criminal sentences. A person who has not been prosecuted as an accused, or a person not brought to trial by a court cannot be detained in this case. When applying a detention measure, there must be a detention order approved by the Procuracy of the same level, without approval will be considered invalid and citizens have the right to not comply.

In addition, when there are signs that the criminal does not intend to evade the law and does not make difficultly the investigation, prosecution, adjudication, and enforcement activities, when there are signs that the offender detention (not even detention) but other deterrent measures possible. For example, a person who commits a first-time crime with a less serious or unintentional crime, has a job, a clear residence, does not have any action to obstruct the investigation, prosecution or adjudication is not detention; Because, the purpose is to prevent the accused's criminal conduct and legal evasion.

\section{PROPOSING RESPONSIBILITY TO COMPENSATE THE ACCUSED FOR POLITICAL, SOCIO-ECONOMIC DAMAGES DUE TO INJUSTICE IN THE COURSE OF INVESTIGATION OF A CRIMINAL CASE}

The State's regime of responsibility to compensate for damages caused by civil servants' illegal acts while on duty is a concept that has become increasingly familiar in a rule of law state and has become one of tools to ensure democracy and social justice, especially to protect the legitimate rights and interests of citizens in their relations with public agencies.

Institutional compensation is a common phenomenon in many countries. This institution has a common feature: in relations with the people, the State and individual public servants are jointly responsible for compensating for the material and mental damage of the person who is wrongly caused by that public servant. when conducting legal proceedings. The unjust person could be a citizen of that country or a foreigner; and the State's responsibility to the people reflected in the provisions of the law as a basis for the division of responsibilities and ensuring that the compensation is resolved in a simple, fast and convenient way for the people. .

In order to have a legal basis for the assignment of compensation for damages for wrongdoings caused by legal proceedings, the State should soon issue a document with high legal effect (law or command) to fully regulate this issue. At the same time, it is necessary to develop a Civil Procedure Code; amending and supplementing the Criminal Procedure Code, the Government organization laws, the People's Courts and the People's Procuracies to be able to synchronously adjust related issues in these documents. For example, as proposed below to assign the court to consider and decide the compensation should be added to the provisions of the Law on Organization of the People's Courts.

As for the assignment of liability for damages, it is necessary to study to clarify two issues: the first is the division of responsibility among procedural agencies: Within the reference we have Many countries do not specifically regulate this issue. Perhaps, it comes from the point of view that the State - as a public representative must be responsible to compensate the people, followed by the issue of the liability of the individuals who have the authority to proceed. Proceedings have caused injustice. The assignment of responsibilities at each stage of the proceedings should also be based on the statutory authority of each agency when making decisions to apply preventive measures, inadequate procedural measures leading to injustice at the stage; Secondly is the issue of separating responsibilities between agencies and individuals who conduct wrongful proceedings: Basically, the current provisions of the Civil Code, Decree No. 47, Circular No. 54 are appropriate. legal documents that can be kept in a law or ordinance that will be drawn up. 


\begin{abstract}
Although the last stage, the order and procedures for compensation settlement are very important. The principles of compensation settlement such as: the settlement must be promptly, promptly, conveniently and publicly available to the people; encourages the voluntary exercise of the compensation liability of proceeding agencies and individuals; ensure the right of individuals to participate and make decisions on their own in the process of compensation for damages; The right of the wrongful person to be finally settled with a decision, court judgment, etc., needs to be legalized. The reducing procedure of many countries is worth reference and can be applied in Vietnam, because it ensures the above principles, especially the Compensation Settlement Council model. of the Chinese Court. The assignment of the people's court to perform the focal point of compensation settlement has many advantages such as: creating a one-stop shop without having to establish a new agency in the current administrative reform conditions. Judges generally have basic training and extensive experience in adjudication of compensation cases; Judicial proceedings are statutory, a public trial of the court are important factors to implement the principles of compensation settlement as mentioned above. In the current conditions of international integration, one of the common principles that all nations must adhere to when participating in international treaties is to ensure that citizens of member countries have the right to adjudicate cases relating to their legitimate rights and interests by a judicial proceeding.

In addition to the above specific recommendations, it is also necessary to invest in research to take radical and sustainable measures, to reduce the number of wrongful cases. In order to do this, it is necessary to take measures to comprehensively affect the quality of activities of the proceeding agencies, such as: improving the professional capacity of each judicial position; strengthening legal responsibility for each specific case assigned to handle; reform and implement reasonable policies on wages and material treatment; attaching responsibility with commendation and discipline to the contingent of judicial officials and employees.
\end{abstract}

\section{CONCLUSION}

Thus, it can be seen that the issue of extending the rights of the accuseds in the investigation process has a great influence on the investigation and enhances the responsibility of the person conducting the investigation, investigating the investigation and reviewing the investigation trial. The extension of the rights of the accuseds should not be seen as weakening the fight against crime. Investigators need to use all skills to collect evidence of accusations and pleadings, aggravating or mitigating the responsibility of the accused, the Court should perform its functions and duties ensure fairness, correctness and accuracy in the trial process.

\section{REFERENCES}

[1] Q.X. Dinh, The Political Economy of Vietnam's Transformation Process, Contemporary Southeast Asia, 22(2) (2000) 360-388.

[2] P. Boettke, et al. The Political, Economic, and Social Aspects of Katrina, Southern Economic J., 74(2) (2007) 363-376.

[3] L.M. Holscher, Recent Legal and Political Changes in Vietnam and the Role of the Courts in the Vietnamese Criminal Justice System. Int. Criminal Justice Review, 6(1) (1996) 58-78. doi:10.1177/105756779600600104

[4] Communist Vietnam outlines property rights in civil code. (1995, October 29). New York Times, p. 4-4.

[5] F. R. Burke, D. Howell, Vietnam: A legal brief. Hanoi, Vietnam: The State Publishing House, 1993.

[6] T.H. Duong, Organizing and functioning of the people's courts in Vietnam. Vietnam Law and Legal Forum, 1(4) (1994) 28-29.

[7] P. HarmsenVietnam investments no longer a piece of cake. The China Post, 1995.

[8] M. Hiebert, Vietnam: Miles to go. Far Eastern Economic Review, 1993, pp. 24-26.

[9] Q.H. Vuong, Vietnam's Political Economy: A Discussion on the 1986-2016 Period (May 21, 2014). CEB-ULB WP N ${ }^{\circ} 14 / 010$ (2014). DOI: $10.2139 /$ ssrn.2439809.

[10] Farewell to poppy fields: The story of the elimination of opium poppy in Vietnam. (1995, February 16-22). The Saigon Times, pp. 13-14.

[11] Feinberg, G. Vietnam: Reestablishing the rule of law: Triumphs and challenges (Part 1). J. Int., 11(6) (1995) 13-16. 


\section{REFERENCES}

[1] Q.X. Dinh, (2000). The Political Economy of Vietnam's Transformation Process, Contemporary Southeast Asia, 22(2), 360-388.

[2] P. Boettke, et al. (2007). The Political, Economic, and Social Aspects of Katrina, Southern Economic J., 74(2), 363-376.

[3] L.M. Holscher, (1996). Recent Legal and Political Changes in Vietnam and the Role of the Courts in the Vietnamese Criminal Justice System. Int. Criminal Justice Review, 6(1). 58-78. doi:10.1177/105756779600600104

[4] NYT. (1995). Communist Vietnam outlines property rights in civil code. (1995, October 29). New York Times, p. 4-4.

[5] F.R. Burke, D. Howell, (1993). Vietnam: A legal brief. Hanoi, Vietnam: The State Publishing House, 1993.

[6] T.H. Duong, (1994). Organizing and functioning of the people's courts in Vietnam. Vietnam Law and Legal Forum, 1(4), 28-29.

[7] P. Harmsen, (1995). Vietnam investments no longer a piece of cake. The China Post, 1995.

[8] M. Hiebert, (1993). Vietnam: Miles to go. Far Eastern Economic Review, 1993, pp. 24-26.

[9] Q.H. Vuong, (2014). Vietnam's Political Economy: A Discussion on the 1986-2016 Period. CEB-ULB WP N 14/010. DOI: 10.2139/ssrn.2439809. (May 21, 2014)

[10] The Saigon Times (1995). Farewell to poppy fields: The story of the elimination of opium poppy in Vietnam. (1995, February 16-22). The Saigon Times, pp. 13-14.

[11] Feinberg, G. (1995). Vietnam: Reestablishing the rule of law: Triumphs and challenges (Part 1). J. Int., 11(6), 13-16. 